\title{
Agnieszka Piela, Stownik frazeologizmów z archaizmami. Pamiątki przeszłości, Wydawnictwo Naukowe PWN,Warszawa 2018, ss. 346
}

Praca Agnieszki Pieli sytuuje się w obszarze historycznej (prymarnie, choć faktycznie także współczesnej) frazeologii polskiej. Sądzę, że autorka po prostu traktuje diachronicznie dynamicznie rozumianą współczesność językową jako ostatnią fazę historii języka - co osobiście jest mi bardzo bliskie. Tymczasem historyczna frazeologia to teren relatywnie słabo dotąd rozpoznany przez badaczy. I to jest pierwsza, dla historyka języka polskiego najważniejsza naukowa przesłanka stanowiąca o wartości opracowania Agnieszki Pieli.

Ma całkowicie rację autorka, twierdząc, że ,istniejące słowniki ogólne oraz frazeologiczne języka polskiego nie dają wyobrażenia o bogactwie i rozmaitości archaicznych wyrazów i ich form "skostniałych» w połączeniach wyrazowych” (s. 8). Tak zatem formułuje sama cel swego opracowania: „Ustalenie zasobu współcześnie występujących frazeologizmów i przysłów z archaicznym komponentem, a tym samym wskazanie łączności między dawną a współczesną polszczyzną - oto nadrzędne cele, jakie przyświecały autorce słownika podczas opracowywania niniejszego zbioru. Zwłaszcza że związki z archaizmami zajmują marginesową pozycję w opisach leksykograficznych, a przecież one również wchodzą w skład zasobu słownego użytkowników polszczyzny XXI w.” (s. 8). Szczególnie bym tutaj podkreślił ten związek między dawną a współczesną polszczyzną. Sam też jestem zdania (czemu zresztą dałem wyraz na piśmie), że wielu zjawisk językowych nie można wytłumaczyć wyłącznie z punktu widzenia współczesnego języka polskiego. Innymi słowy, między polszczyzną dawną i współczesną istnieją liczne powiązania, a dzisiejszego stanu polszczyzny niepodobna do końca zrozumieć i opisać bez znajomości jej dziejów [zob. Walczak 2006]. Trudno tutaj nie zauważyć, że to przekonanie („historia pozwala nam lepiej rozumieć fakty współczesnego języka pol- 
skiego", s. 8) autorka dzieli z całą śląską szkołą językoznawstwa historycznego (Krystyna Kleszczowa, Magdalena Pastuchowa, Alicja Janowska itd.), która usilnie podkreśla w swoich badaniach istnienie licznych pomostów łączących polszczyznę historyczną i współczesną.

Na skutek takiej postawy i tak nakreślonych celów autorka ma pełne prawo twierdzić, że jej publikacja „wypełnia lukę w polskiej leksykografii - dotąd nie powstał dykcjonarz mieszczący tego typu związki wyrazowe. Słownik ma nowatorski charakter. Udokumentowane w nim utarte połączenia z przeżytkami fonetycznymi, fleksyjnymi, słowotwórczymi, leksykalnymi, semantycznymi, składniowymi ukazują skalę dziedzictwa kulturowo-językowego w polszczyźnie XXI wieku" (s. 8).

Autorka stawia również w tym względzie trafną diagnozę - opracowanie takie nie powstało, gdyż „niełatwo [...] wykryć wszystkie ślady historycznej polszczyzny obecne we współczesnym języku polskim" (s. 9). Sama autorka tropi je z imponującym, nieraz iście detektywistycznym zacięciem (jak i cała śląska szkoła językoznawstwa historycznego), mimo to jednak sumituje się, że zgromadzony przez nią materiał nie jest - bo z natury swej być nie może kompletny: „Słownik pod względem materiałowym nie jest kompletny” (s. 9). Zgadzam się, że ,trudno do tego typu konstrukcji [związków z archaicznym członem - B.W.] dotrzeć, trudno je «wyłowić» z zasobu frazeologicznego współczesnej polszczyzny" (s. 9). Nie sposób stwierdzić, co we frazeologii należy już do archiwum językowego [zob. Handke 1997], a co jest jeszcze w użyciu. Tutaj zresztą autorka przyjęła dobre kryterium w postaci świadectwa przykładów zaczerpniętych z Narodowego korpusu języka polskiego i z wybiórczo potraktowanych dzieł literackich.

W tym miejscu należy zauważyć, że moim zdaniem w takim opracowaniu zasadne (ze wszech miar zasadne) jest przyjęte przez autorkę szerokie rozumienie frazeologii (łącznie z przysłowiami, najszerzej znanymi zestawieniami terminologicznymi itd.) - expressis verbis Agnieszka Piela pisze: ,przyjmuję szerokie rozumienie frazeologizmów. Zaliczam do nich również przysłowia czy zestawienia terminologiczne, choć zdaję sobie sprawę, że w obrębie frazeologii mają one różny status" (s. 7). Jest to rozumienie bliskie koncepcji frazematyki Wojciecha Chlebdy - w przypisie 2 na s. 7 autorka pisze o ,gotowych strukturach językowych”: ,wszystkie wielowyrazowe konstrukcje łączy to, że stanowią one gotowe struktury językowe" (,gotowe" to chyba tyle - przynajmniej ja tak to rozumiem - co odtwarzane w całości, w gotowej postaci, a nie tworzone).

Mimo takiego szerokiego rozumienia frazeologii autorka musiała przyjąć pewne ograniczenia. Pisze o tym przekonująco na s. 9-10. Można oczywiście żałować (choć trzeba przypomnieć, że sam słownik, bez jakiejkolwiek obu- 
dowy, liczy aż 208 stron), iż autorka musiała wyłączyć ze swojego zbioru takie terminy, jak: bieg wsteczny, lusterko wsteczne, narząd rodny, plug koleśny czy rzut rożny: „W opracowanym zbiorze nie uwzględniono w postaci odrębnych artykułów hasłowych archaizmów zawartych w terminologii specjalnej, np. pług koleśny (archaizm koleśny 'dotyczący pojazdu na kołach; kołowy'); narząd rodny (archaizm rodny 'płodny, rodzący, urodzajny, żyzny'); rzut rożny (archaizm rożny 'umieszczony na rogu czegoś'); straż pożarna (przestarzały przymiotnik: pożarny - od pożar); lusterko wsteczne; bieg wsteczny (przestarzały wsteczny 'kierowany wstecz, w tył'). I choć niektóre z wymienionych terminów są dobrze znane Polakom, to jednak większość tego typu połączeń występuje w specjalistycznych odmianach polszczyzny. Stąd decyzja o ich wykluczeniu ze zbioru" (s. 9-10).

Wreszcie w całej rozciągłości należy zaakceptować to, co autorka napisała na s. 11 o przeznaczeniu i przewidywanych odbiorcach (adresatach) jej dzieła: „Słownik frazeologizmów z archaizmami. Pamiątki przeszłości jest odpowiedzią na postulaty zintensyfikowania badań nad stałymi połączeniami wyrazowymi przechowującymi w swoim składzie wymarłe już elementy języka polskiego. Jednak słownik przeznaczony jest nie tylko dla specjalistów (językoznawców), jego adresatami mogą być również miłośnicy mowy ojczystej - wszyscy, którzy chcą poszerzyć wiedzę na temat mowy naszych przodków. Słownik może być traktowany jako baza źródłowa do badań nad historią i kulturą języka polskiego (rozwój rodzimej frazeologii, refleksja nad semantyką i etymologią «skostniałych»w połączeniach słów). Może też służyć do studiów bardziej ogólnych, np. badań porównawczych związków z archaizmami w różnych językach słowiańskich. Przydatność słownika widzę także w dydaktyce akademickiej - na zajęciach z historii języka polskiego, gramatyki historycznej języka polskiego, leksykologii i leksykografii, kultury języka polskiego (fakty historyczne obecne w mowie współczesnej). Niniejsza publikacja jest wreszcie źródłem ciekawostek językowych (przydatnych w kształceniu językowym i literackim uczniów), z których można czerpać wiedzę na temat historii języka polskiego".

Nie budzą też wątpliwości przyjęte przez autorkę definicje archaizmu, anachronizmu (wyrazu przestarzałego) i historyzmu (czyli archaizmu tzw. rzeczowego) ani zastosowana $\mathrm{w}$ odniesieniu do zgromadzonego materiału najprostsza, ale - jak autorka sama podkreśla - najczęściej przyjmowana klasyfikacja archaizmów ze względu na naturę archaiczności (tzn. klasyfikacja na archaizmy fonetyczne, fleksyjne, słowotwórcze, leksykalne - tu granica jest często trudna do wykreślenia, semantyczne i składniowe). 
Za uzasadniony trzeba też uznać termin tradycjonalizm, definiowany przez autorkę następująco: „,funkcjonująca we współczesnej polszczyźnie konstrukcja wyrazowa mieszcząca w swoim składzie jakikolwiek archaiczny element języka, będący pozostałością po wcześniejszych etapach rozwojowych polszczyzny (np. archaizm fonetyczny, fleksyjny, semantyczny [...]). W zależności od rodzaju archaizmu utrwalonego w różnych konstrukcjach wyrazowych można wyodrębnić następujące typy tradycjonalizmów:

1) $\mathrm{z}$ archaizmem fonetycznym $[\ldots]$;

2) $\mathrm{z}$ archaizmem fleksyjnym [...];

3) z archaizmem słowotwórczym [...];

4) $\mathrm{z}$ archaizmem leksykalnym [...];

5) $\mathrm{z}$ archaizmem semantycznym [...];

6) $\mathrm{z}$ archaizmem składniowym [...]" (s. 13-14).

I wreszcie za trafny uznaję dobór słowników, z których autorka czerpała materiał: „Podstawę materiałową stanowią dwa ogólne słowniki języka polskiego: Uniwersalny słownik języka polskiego pod redakcją Stanisława Dubisza oraz Współczesny stownik języka polskiego w opracowaniu naukowym Bogusława Dunaja. Wymienione leksykony wybrano z uwagi na to, że sporo miejsca poświęcają one «przeżytkom» językowym, szeroko uwzględniają archaiczne elementy języka polskiego, choć w odmienny sposób je hasłują" (s. 17). Nie budzą żadnych wątpliwości ani nie nasuwają żadnych uwag krytycznych wyzyskane pomocniczo słowniki historyczne, etymologiczne, frazeologiczne i źródła paremiologiczne: „W opisie dawnych komponentów związków wyrazowych korzystano również ze źródeł historycznych. Wiadomości na temat starych form językowych czerpano ze Stownika staropolskiego, Stownika polszczyzny XVI wieku, Stownika języka polskiego Samuela Bogusława [powinno być oczywiście: Bogumiła-B.W.] Lindego, Stownika języka polskiego XVII i 1. połowy XVIII wieku, z tzw. Stownika wileńskiego i Stownika warszawskiego oraz ze Słownika języka polskiego pod redakcją Witolda Doroszewskiego [autorka trafnie go uznała za słownik historyczny - B.W.]. Ponadto wykorzystano źródła frazeologiczne i paremiologiczne: Stownik frazeologiczny języka polskiego Stanisława Skorupki oraz Nowa księgę przystów i wyrażeń przystowiowych polskich w redakcji Juliana Krzyżanowskiego. Ważnym źródłem informacji były również słowniki etymologiczne: Słownik etymologiczny języka polskiego Franciszka Sławskiego, Stownik etymologiczny języka polskiego Aleksandra Brücknera, Etymologiczny słownik języka polskiego Andrzeja Bańkowskiego, Stownik etymologiczny języka polskiego Wiesława Borysia oraz Polski słownik etymologiczny Witolda Mańczaka. Uzupełnienie podstawowej bazy źródłowej stanowiły następujące leksykony: Mirosława Bańki: Słownik porównań, Jana 
Karłowicza: Słownik gwar polskich, Władysława Kopalińskiego: Słownik eponimów, czyli wyrazów odimiennych. Ważną rolę w opracowaniu niniejszego słownika odegrały również opracowania encyklopedyczne o charakterze kulturowym (Encyklopedia staropolska Aleksandra Brücknera i Encyklopedia staropolska ilustrowana Zygmunta Glogera)" (s. 18).

Polska leksykografia wzbogaciła się o bardzo potrzebny i wartościowy słownik.

Bogdan Walczak

\section{Bibliografia}

Handke Kwiryna (1997), ,, Czasowe cezury” i przebieg życia wyrazu, w: tejże, Rozważania i analizy językoznawcze. Wybór prac z okazji 65. urodzin Autorki, Warszawa, s. $55-69$.

Walczak Bogdan (2006), Diachronia w synchronii, czyli czy można rozumieć język bez historii, w: O historyczności, red. Katarzyna Meller, Krzysztof Trybuś, Wydawnictwo „Poznańskie Studia Polonistyczne”, Poznań, s. 323-330. 
